\title{
Laboratory evaluation of susceptibility tests for National Antimicrobial Resistance Surveillance System (NAMRSS) in Turkey
}

\section{Türkiye'de Ulusal Antimikrobiyal Direnç Sürveyans Sistemi (UAMDSS) için duyarlılık testlerinin laboratuvar değerlendirmesi}

\author{
Efsun AKBAŞ ${ }^{1}$, Nilay ÇÖPLÜ2${ }^{2}$, Hüsniye şiMŞEK ${ }^{3}$, Berrin ESEN ${ }^{4}$, Berna SEZGiN${ }^{3}$
}

\section{ABSTRACT}

Objective: Antimicrobial resistance is a growing problem worldwide, and to combat with this problem some measures should be taken. One of them is analysis of current situation and National Antimicrobial Resistance Surveillance System (NAMRSS) was established for this purpose. The quality of the data depends on the participating laboratories performance, so there was need for an assessment of the laboratories in the system. This study was aimed to analyse the status of the participating laboratories for antimicrobial susceptibility testing requirements.

Methods: There were 77 participating laboratories selected for NAMRSS throughout the country. Twentyfive of them were included in for capacity analysis study. A Laboratory Assessment Tool (LAT) was used for the evaluation of laboratories with 'checklist' features, and face-to-face interviews were used. LAT was a programme containing 677 questions in 10 modules that were developed by World Health Organization (WHO). A set of questions were added to use for antimicrobial susceptibility tests (AST). Teams were formed from a total of 33 volunteer experts who received training prior to laboratory visits in a workshop, and there were

\section{ÖZET}

Amaç: Antimikrobiyal direnç dünya çapında büyüyen bir problemdir ve bu problem ile savașmak için bazı önlemler alınmalıdır. Mevcut durum analizi bunlardan biridir ve Ulusal Antimikrobiyal Direnç Surveyans Sistemi (UAMDSS) bu amaçla kurulmuștur. Verilerin kalitesi katılımcı laboratuvarların performansına bağlıdır, o nedenle sistemdeki laboratuvarların değerlendirilmesine ihtiyaç olmuştur. $\mathrm{Bu}$ çalıșma, katılımcı laboratuvarların antimikrobiyal duyarlılık testi ihtiyaçları için durumlarını analiz etmeyi amaçlamaktadır.

Yöntem: UAMDSS için ülke çapında seçilmiş 77 katılımcı laboratuvar bulunmaktadır. Kapasite analizi çalıșmasına bunlardan 25 adedi dahil edilmiștir. Laboratuvarların değerlendirilmesi için 'kontrol listesi’ özellikleri olan bir Laboratuvar Değerlendirme Aracı (LAT) yüz yüze görüșmelerle kullanılmıștır. LAT, Dünya Sağlık Örgütü (DSÖ) tarafından geliștirilmiș, 10 modülde 677 soru içeren bir programdır. Antimikrobiyal duyarlılık testleri (ADT) için sorular eklenerek kullanılmıștır. Laboratuvar ziyaretleri öncesinde, bir çalıștayda eğitim alan toplam 33 gönüllü uzmandan ekipler olușturuldu ve her ekipte

${ }^{1}$ Technical Advisor, World Health Organisation (WHO), Ankara

${ }^{2}$ Kastamonu University Kastamonu Medical School, Medical Microbiyology AD, Kastamonu

${ }^{3}$ Public Health Agency of Turkey, Directorate of Microbiology Reference Laboratories, Ankara

${ }^{4}$ Ankara Training and Research Hospital, Microbiology Department, Ankara

İletişim/ Corresponding Author : Nilay ÇÖPLÜ

Diskapi Y. Beyazit Tra. and Res. Hos. Mic. Dep. Irfan Bastug St. Diskapi, Ankara - Türkiye

Tel : +905325461611 E-posta/E-mail : nilaycoplu@gmail.com

Geliş Tarihi / Received : 31.05 .2017 Kabul Tarihi/ Accepted : 15.02 .2018

DOI ID : 10.5505/TurkHijyen.2018.89166

Akbas E, Cöplü N, Simsek H, Esen B, Sezgin B. Laboratory Evaluation of susceptibility tests for National Antimicrobial Resistance Surveillance System (NAMRSS) in Turkey. Turk Hij Den Biyol Derg, 2018; 75(1): 1-12 
at least two people in each team. They have visited the laboratories for implementing the LAT. Data were transferred to a database and analysed for both general conditions, and AST capacity.

Results: Laboratories were distributed institutionally as university hospital $(n=17)$, training and research hospital $(n=4)$, state hospital $(n=2)$ and military hospital $(n=2)$. NAMRSS laboratories performed identification and AST by automated systems as well as disc diffusion and minimum inhibitory concentration (MIC) tests except for one laboratory. Also, the laboratories were generally in 'good standing' (approx. $>85 \%$ ) for three of the modules, where the other modules suggest that there are issues that 'need some improvements' at different degrees. When focused on AST, outside of internal quality control applications, it was observed that availability for AST culture media and reagents, identification and AST capacity are between $84-95 \%$. It was found that total quality was $67 \%$.

Conclusion: NAMRSS laboratories seem to be able to provide reliable results in AST, which is essential for both surveillance system and evidence based decisions in effective treatment of patients. On the other hand, improvement in some other issues is necessary.

Key Words: antimicrobial resistance, bacterial, surveillance, quality control

\section{INTRODUCTION}

The development of resistance to antimicrobials is among the most important health problems both in our country and in the world (1). Antimicrobial resistance (AMR) surveillance provides basic data for developing strategies, monitoring the effectiveness of public health interventions and detecting new trends and threats. The "National Antimicrobial Resistance Surveillance System (NAMRSS)" was established for these purposes in Turkey, and the first data collection and report took place in 2011 (2). Coverage of this en az iki kiși bulunmaktaydı. LAT'ı uygulamak için bu ekipler laboratuvarları ziyaret etmiștir. Veriler bir veritabanına aktarılmıștır ve hem genel koșullar, hem de ADT kapasitesi için analiz edilmiștir.

Bulgular: Laboratuvarların kurumsal dağılımı üniversite hastanesi ( $n=17)$, eğitim ve araștırma hastanesi $(n=4)$, devlet hastanesi $(n=2)$ ve askeri hastane $(n=2)$ șeklindeydi. UAMDSS laboratuvarları, biri hariç tanımlama ve ADT otomatize sistemlerin yanısıra disk difuzyon ve minimum inhibitör konsantrasyon (MIK) testleri ile yapmaktadır. Ayrıca, laboratuvarlar modüllerden üçü için genellikle "iyi durumda” (yaklașık $>\% 85$ ) olup diğer modüller, farklı derecelerde "bazı gelișmelere ihtiyaç duyan” sorunlar olduğunu öne sürmektedir. İç kalite kontrol uygulamaları dışındaki ADT'ye odaklandığında, ADT kültür ortamı ve reaktifleri için kullanılabilirlik, tanımlama ve ADT kapasitesinin \%84-95 arasında olduğu gözlenmiștir. Toplam kalite gerekliliklerinin sağlanması \%67 olarak bulunmuștur.

Sonuç: UAMDSS laboratuvarlarının hem sürveyans sistemi, hem de hastaların etkin tedavisinde kanita dayalı kararlar için gerekli olan ADT'de güvenilir sonuçlar sağlayabildikleri görülmektedir. Öte yandan, bazı diğer konularda iyileștirme gerekmektedir.

Anahtar Kelimeler: antimikrobiyal direnç, bakteriyel, sürveyans, kalite kontrol

system was in accordance with the surveillances of the World Health Organization (WHO) and European Union (EU) programmes $(1,3)$.

Laboratories for NAMRSS were selected according to the score obtained from a questionnaire applied to the laboratories during the establishment period (4). Besides, NAMRSS has published a document including standard operating procedures (SOP) of laboratory tests, quality control and quality assurance for antimicrobial susceptibility testing (AST), and 
WHONET software porgramme (5). Training courses were organized, where the contents of the document was explained and distributed. On the other hand, still there was need for internal quality control (IQC) and external quality assurance (EQA) studies to rely on the AST results of these laboratories. For EQA purposes, two studies were performed: onsite supervision study, and a proficiency assesment study, in 2011(6). In this context, EQA on-site supervision study was included in another survey titled “Implementation of Laboratory Assessment Tool (LAT): Capacity Analysis of Microbiology Laboratories in Diagnosis of Communicable Diseases for the Purposes of Surveillance and Outbreak Investigations" which was performed by Communicable Disease Surveillance and Control Project in Turkey, Phase III (TR0802.16), by adding some queries targeted for AST applications. The objective of this study was to bring out the capabilities of NAMRSS laboratories for performing AST by using an assessment tool.

\section{MATERIAL and METHOD}

\section{Laboratory Assessment Tool (LAT)}

A LAT was used for the evaluation of laboratories in this study with 'checklist' features and face-to-face interviews (7). LAT is a simple MS Excel programme developed by the WHO, assessing microbiology laboratories both in terms of technical and administrative capacities. LAT software automatically calculates the values of the replies and the "indicator values" are obtained. There are many indicators in each module and the average of the values of these indicators has a numerical expression of the status of the laboratory. By LAT, 677 questions in 10 sections were asked, with an addition of 11 questions related with AST and total quality. This study was done in 2011.

\section{Selection of the Laboratories}

Twenty five of NAMRSS member laboratories were in common with the afore mentioned implementation of LAT study, where there was need to meet at least one of the following criteria: (a) a consistent distribution throughout the country (26 provinces in 12 regions of Turkish Nomenclature of Territorial Units for Statistics), (b) being in one of the pilot provinces for early warning and response system which would be established by the Ministry of Health within the framework of the EU Project (Surveillance and Control of Communicable Diseases Project; TR0802.16-01), (c) being located nearby the land or sea gates; (d) existence of the persistent qualified personnel (specialist).

\section{Establishment of LAT implementation teams}

Team members who were going to join this study were selected among clinical microbiology specialists and preferably those who participated in laboratory audits previously. Teams were formed from a total of 33 volunteer experts who were trained prior to laboratory visits in a three-day workshop, and there were at least two people in each inspection team.

\section{Field Implementation of LAT}

Field implementation of LAT occurred in between 13th September and 30th October 2011. The teams visited the laboratories for a full working day. For each laboratory, face-to-face interviews were done with the laboratory manager, on-site observation of the laboratory was performed, and the questionnaire was filled and recorded electronically. At the same time, feed-back was provided to the staff of the laboratories. The evaluation was done by indicator values: (i) require significant improvement below $50 \%$, (ii) need some improvement between 50 and $85 \%$, (iii) the laboratory is in good standing above $85 \%$. In addition, the laboratories were classified according to their levels: Level - 1 (peripheral level) laboratory which serves a district or province; Level 2 (regional level) laboratory which serves to a larger area than a district or province; Level - 3 (advanced/ reference level) laboratory that can use advanced methodologies and molecular techniques and/or 
those accepted as national laboratory by the Ministry of Health, serving across the country. Each laboratory was analysed by the LAT programme according to its level.

\section{RESULTS}

Laboratories were distributed institutionally as university hospital $(n=17)$, training and research hospital $(n=4)$, state hospital $(n=2)$ and military hospital $(n=2)$. Majority of the NAMRSS laboratories $(n=21)$ were Level -2 , whereas two state hospitals were Level -1 and two university hospitals were Level - 3. Yet many of these laboratories $(n=23)$ belonged to hospitals with a capacity of over 500 beds.

Table 1 shows the average numerical values of practices and capacities of the laboratories for the modules covered in the LAT survey. Accordingly, it was observed that usually the NAMRSS laboratories were in 'good standing' (above 85\%) in terms of building facilities and services; specimen collection and recording; laboratory staff and working time. Other modules showed that there was 'need some improvements' (50-85\%) at different levels in NAMRSS laboratories examined, including "total quality" (67
\%) which has a priority for this study.

The modules that need some improvement were given in Table 2 . It was noteworthy that the indicators such asuse of personal protectiveequipment, existence of written safety procedures, safety trainings and internal quality control (IQC) practices for AST were quite low in NAMRSS participating laboratories. The lowest indicator was 'inter-laboratory collaboration and supervision' ( $43 \%$ ) which were followed by the indicators on 'resource availability for reagents' (48 $\%)$ and 'external quality assurance (EQA) certification or accreditation practices' ( $52 \%$ ). On the other hand, when focused on AST, other than IQC applications, it was observed that availability of AST culture media and reagents, identification and AST capacity were in between $84-95 \%$.

When the equipment and capacity of NAMRSS laboratories were analyzed in terms of identification and AST, it was found that all the NAMRSS laboratories, except one, used automated systems. When usage of the conventional tests was asked, it was understood that up to 8 of the labs did conventional tests such as motility test, triple sugar iron agar or Kligler iron agar

Table 1. Capacities (the averages of indicator values as percentage) of the laboratories by 'modules' in the LAT inquiry

\begin{tabular}{ll}
\hline Modules of LAT & $\begin{array}{c}\text { Average of indicator values for } \\
\text { NAMRSS labs (n = 25) }\end{array}$ \\
\hline 1 - building facilities and utility services & $86 \%$ \\
2 - biosafety, hygiene and waste management & $66 \%$ \\
3 - specimen collection and recording & $84 \%$ \\
4 - equipment & $71 \%$ \\
5 - reagents, consumables and supply & $72 \%$ \\
6 - analysis and tests performed & $75 \%$ \\
7 - laboratory staff and working time & $84 \%$ \\
8 - total quality & $67 \%$ \\
9 - reporting, analysis \& communication & $78 \%$ \\
10 - public health action / outbreak participation & $68 \%$ \\
\hline Overall average & $75 \%$
\end{tabular}


Table 2. The status of laboratories according to the issues investigated in some question groups (indicators) in some modules of the LAT

Some modules and their indicators

NAMRSS labs

( $n=25)$

1. Biosafety, hygiene and waste management

$66 \%$

Use of personal protective equipment

$64 \%$

Existence of written safety procedures

$64 \%$

Level of the safety trainings

$62 \%$

Equipment disinfection / sterilization

$66 \%$

8. Total quality

$67 \%$

General situation relating to quality practices

$60 \%$

Existence of written technical procedures

$70 \%$

Availability of Internal Quality Control (IQC)

$82 \%$

IQC applications for Antimicrobial Susceptibility Testing (AST)

$63 \%$

External Quality Assessment (EQA) / certification / accreditation

$52 \%$

Availability of the follow-up sheets (temperature charts, etc.)

$68 \%$

Availability of the equipment inventory

$61 \%$

Preventive maintenance for equipment

$70 \%$

Equipment calibration

$66 \%$

Keeping user manuals and spare parts

$74 \%$

5.Reagents, consumables and supplies

Preparation of reagents using raw materials or powders

$69 \%$

Quality of the reagent management

$71 \%$

Resource availability for reagents

$48 \%$

Availability of AST culture media and reagents

$95 \%$

Availability of specific antisera

$55 \%$

6. Analysis and tests performed, $75 \%$

Availability of diagnostic tests for the target diseases

$67 \%$

Availability of AST capacity

$88 \%$

Availability of identification capacity

$84 \%$

Availability of advanced identification capacity

$61 \%$

Availability of advanced specialized testing capacity

$56 \%$

9.Reporting, analysis \& communication

$78 \%$

Data analysis and statistics can be performed

$75 \%$

Notification (diseases, resistance etc.) is done

$83 \%$

Inter-laboratory collaboration and supervision

$43 \%$ 
passages, IMViC tests, oxidase, catalase, coagulase, bile solubility, salt tolerance, and PYR tests. Besides all of the labs were able to use the disk diffusion test and the tests for detection of MIC's, except one university laboratory. The MIC detection was done in 21 labs for oxacillin, teikoplanin and ceftriaxone; 22 for cefotaxime; 23 for penicillin; and 24 for vancomycin, which were the antimicrobial agents those were asked to study in SOP documentations. Besides, agar screening test for oxacillin and vancomycin could be performed in 17 of the laboratories. The condition of these laboratories in terms of necessary reagents and supplies for AST were given in Table 3. It was seen that each of the NAMRSS participating laboratories performed an average of 10,000 AST (min. 1123 max. $37,000)$ in a year.

These laboratories were also questioned about stock management (Table 4) and IQC practices (Table 5) related with AST. It was noteworthy that nearly

Table 3. Availability of the reagents and supplies required in AST in the NAMRSS laboratories

\begin{tabular}{lccc}
\hline Reagents / Supplies & Always & $\begin{array}{c}\text { Sometimes } \\
\text { ( } 6 \text { months, years })\end{array}$ & Never \\
\hline Mueller-Hinton agar medium & & 0 & 0 \\
Mueller-Hinton broth & 25 & 2 & 2 \\
Plastic Petri dishes for AST & 21 & 0 & 2 \\
Antibiotic discs for AST & 23 & 0 & 0 \\
ESBL* disks or G-test strips for AST & 25 & 0 & 2 \\
McFarland turbidity standard & 23 & 0 & 1 \\
Standard strains (ATCC or NTCC) & 24 & 2 & 0 \\
\hline
\end{tabular}

* extended spectrum beta lactamases

half of the NAMRSS laboratories were not using 'minimum stock levels' set and were not writing the opening date on reagent or kit boxes. Also, it was understood that some or all IQC practices were not implemented in laboratories of state hospitals, many training \& research hospitals and university hospitals (Table 5).

\section{DISCUSSION}

Surveillance is defined as "the systematic ongoing collection, collation and analysis of data" for public health purposes and the timely dissemination of public health information for assessment and public health response as necessary (8). AMR surveillance serves public health purposes; because, when it can be measured at national and international scales, it can be observed that the antimicrobial resistance problem settles distinctly into the context of public health threats (9).

The obligation to monitor AMR at national level was introduced by the "By-law on the Surveillance and Control Principles of Communicable Diseases (amendment)" in Turkey, in 2011 (10). By-law is also a component of objectives for compliance with the relevant legislation of European Union (EU) $(11,12)$. According to this legislation, surveillance is essential for both the execution of programmes against resistance-development in pathogens and the prevention of national and international spread of resistant strains to combat with communicable diseases. Accordingly, based on this legislation, NAMRSS was established in our country to collect antimicrobial resistance data and reveal the dimensions of resistance problem, and the information gained by NAMRSS will be used to develop programmes for the prevention and control 
Table 4. Distribution of "yes" responses given to the questions on the stock management and some general quality practices of NAMRSS member laboratories

\begin{tabular}{|c|c|c|c|c|c|}
\hline & $\begin{array}{l}\text { Military } \\
\text { Hosp. } \\
(n=2)\end{array}$ & $\begin{array}{l}\text { State } \\
\text { Hosp. (n } \\
=2 \text { ) }\end{array}$ & $\begin{array}{c}\text { TRH } \\
(n=4)\end{array}$ & $\begin{array}{l}\text { University } \\
\qquad \text { Lab. } \\
(n=17)\end{array}$ & $\begin{array}{c}\text { Total } \\
(n=25)\end{array}$ \\
\hline \multicolumn{6}{|l|}{ Questions } \\
\hline $\begin{array}{l}\text { Do you prepare reagents and/or media in the } \\
\text { laboratory? }\end{array}$ & 2 & 1 & 3 & $17^{\mathrm{a}}$ & 23 \\
\hline $\begin{array}{l}\text { Do you have a "minimum stock level" set for } \\
\text { reagents/supplies? }\end{array}$ & 2 & 1 & 4 & 7 & 14 \\
\hline $\begin{array}{l}\text { Do you write the opening date of the reagents/ } \\
\text { kits on the containers (bottles)? }\end{array}$ & 2 & 0 & 2 & 10 & 14 \\
\hline $\begin{array}{l}\text { Do you have a staff responsible for stock } \\
\text { managing in your laboratory? }\end{array}$ & 2 & 2 & 4 & 16 & 24 \\
\hline $\begin{array}{l}\text { Do you perform inventories of your stocks? (at } \\
\text { least twice a year) }\end{array}$ & 2 & 1 & 4 & 13 & 20 \\
\hline $\begin{array}{l}\text { Do you regularly check expiration dates of } \\
\text { reagents? }\end{array}$ & 2 & 1 & 4 & 15 & 22 \\
\hline Do you use expired products and reagents? ${ }^{\mathrm{b}}$ & 1 & 1 & 0 & 6 & 8 \\
\hline $\begin{array}{l}\text { Does your laboratory have an "internal audit } \\
\text { program" for quality control? }\end{array}$ & 2 & 0 & 4 & 9 & 15 \\
\hline Does your laboratory have a "Quality Manual"? & 2 & 0 & 4 & 10 & 16 \\
\hline Has your laboratory participated in any & & & & & \\
\hline $\begin{array}{l}\text { External Quality Assessment program for } \\
\text { Antimicrobial Susceptibility Testing? (for at } \\
\text { least two consecutive years)? }\end{array}$ & 2 & 1 & 3 & 12 & 18 \\
\hline
\end{tabular}

TRH, Training \& Researsch Hospital;

a) Five university hospital laboratories have declared "sometimes"

b) In this question, the answers "sometimes" were included in the table. All other laboratories answered as "no". 
Table 5. Distribution of "yes" responses given to the questions on the Internal Quality Control (IQC) practices for Antimicrobial Susceptibility Testing (AST) of NAMRSS laboratories

\begin{tabular}{ccccccc}
\hline & Military & State & & University & Total \\
Questions & Hosp. $(M H)$ & Hosp. & TRH & $(n=4)$ & Lab. & $(n=25)$ \\
& $(n=2)$ & $(n=2)$ & & $(n=17)$ & $(n=17)$
\end{tabular}

Do you apply IQC for AST ? a

Do you perform Quality Control (QC) with

proper AST strains weekly?

Is each new lot of MH agar medium tested by

QC strains?

Do you perform sterility tests for every batch

of the lab made culture media, microdilution

plates or agar plates?

When a new box of MH broth is opened, do you

test cation content with $\mathrm{QC}$ strain?

Do you keep records for each material used

and for each test day?

For growth (viability) control, do you inoculate

the microorganism to be examined to the

medium used in the test?

Do you make culture of each inoculum

suspension to a suitable agar plate for purity

control?

Do you perform check 0.5 McFarland standard

at least monthly?

Are the Minimum Inhibitory Concentration

(MIC) results of staff who makes test being

compared for the purpose of 'results

evaluation check'?

Do you periodically transmit your AST data via

BacLink to NAMRSS?
1

0

1

2

10

2

2

2

2

2

1

2

1

3

a) The following questions were directed to the laboratories that answered as "yes" to this question.
15

17

12

24

18

20

8

15

18

13

22 
of resistance and provide guidance for rational use of antimicrobials.

The selection of NAMRSS laboratories was done by means of the score obtained from a questionnaire study (4). Similar studies has been performed, like ECDC, in close collaboration with the National Microbiology Focal Points and the Advisory Forum, had developed and piloted a system (EU LabCap) for monitoring key public health microbiology capabilities and capacity for EU surveillance and epidemic preparedness (13). Besides, NAMRSS determined microorganisms to survey resistance, antimicrobial agents and test methods during its establishment, which was in accordance with international surveillance systems $(2,3,5,14)$. In this context, to ensure standardization among the members of the laboratory network and in order to guarantee the reliability of the results, NAMRSS published the "standard operating procedures" for AST, organized trainings and conducted EQC trials, including this study $(2,5,6)$.

This study which was carried out in 2011 has been quite important since it enabled the assessment of the baseline situation of the NAMRSS laboratory network during the first year of its establishment. Similar studies for Surveillance systems have been performed to aid correct interpretation of the surveillance data like EARS-Net (15). This study was carried out as an on-site supervision in the context of EQA during the LAT implementation conducted throughout the country.

The average of indicator values revealed that to be 'good standing' in the overall situation there are points that require improvement, such as public health action, biosafety and quality areas. On the other hand, when considering NAMRSS purposes, results showed that the indicator values about public health actions, and the biosafety which is especially important for the staff, did not have priorities, where quality had, for the laboratories. When it is assumed that improvements to be made on quality management would make a positive impact on solving the problems of laboratories under other headings, efforts could focus on the quality area $(16,17)$. It is understood that the laboratories have no problems in terms of supplying AST reagents (indicator value approx. 95\%), however some of the laboratories have inventory management problems and it seems that there is need to improve the conditions. Likewise, the IQC practice for AST in Table 5 shows that there is need to improve IQC practices especially in state hospitals and to some extend in TRH and universities.

On the other hand, NAMRSS has proven to produce trustworthy data even though there are some certain issues to be improved $(6,14)$. A national EQA is being applied to participating laboratories twice a year by Public Health Institution of Turkey since 2011, and in the first study, 58 out of 68 laboratory performed success above the determined threshold $70 \%$, and the system was considered dependable (6). Besides, NAMRSS had joined an international surveillance system, Central Asian and Eastern European Surveillance of Antimicrobial Resistance (CEASERS), WHO (14). The first annual report of CEASERS was published in 2014 which included NAMRSS data of Turkey for 2013 which was regarded as "Level A Data" by the authors. The data presented was judged to be representative for the target population, and the AST results were accepted to be reliable.

One of the key features of LAT is the ability to give on-site feedback, thus providing the opportunity for immediate self-assessment to each laboratory. Accordingly, the study is thought to have a positive impact on the improvement of laboratory network by the on-site feedback, so that the laboratories could be aware of their deficiencies and were able to take measures for remedy. Another key feature of LAT is to allow monitoring the laboratories to determine that indicators have been improved when repeated in time, which will lead to follow up. 
In conclusion, reliability of the laboratory results is essential for evidence based decisions that are needed for efficient treatment of patients as well as for surveillance systems. In this study, findings revealed that even though there were some issues that need to be improved in NAMRSS participating laboratories, the identification and AST parameters were in good condition except IQC. Considering that the network will expand over time, it seems to be important that similar studies should be performed regularly and their results should be shared with the related community.

\section{ACKNOWLEDGMENTS}

We acknowledge all colleagues from NAMRSS member laboratories for participating in the LAT field study. We thank Mustafa Ertek both for scientific advisory and administrative support as the President of the Institute in the time period of this study. We also thank Ray Sanders for scientific advisory as a WHO expert. We are grateful to Berna Sezgin, for smoothly running of administrative procedures, organization of meetings and travels. We acknowledge Laboratory Assesment Tool Field Study Team: Alper Aksozek, Zerrin Aktas, Nurhan Albayrak, Hikmet Eda Aliskan, Sohret Aydemir, Banu Bayraktar, Umut Berberoglu, Rukiye Berkem, Efe Serkan Boz, Burak Ekrem Citil, Ece Dirim, Devrim Dundar, Pinar Etiz, Nese Gol, Revasiye Gulesen, Seda Havuz, Nilgun Karabicak, Tuba Kayman, Selcuk Kilic, Yasar Nakipoglu, Dilara Ogunc, Betul Okten, Tuncer Ozekinci, Nevgun Sepin Ozen, Berna Sezgin, Cemile Sonmez, Husniye Simsek, Aysegul Taylan Ozkan, Senay Tuglu Ataman, Zehra Unal, Dilek Yagci Caglayik, Serap Yagci, Mustafa Yilmaz, and Demet Yumusak. We acknowledge the Scientific Advisory Committee of NAMRSS (in alphabetical order by surnames: Sohret Aydemir, Gulcin Bayramoglu, Riza Durmaz, Gul Bahar Erdem, Mete Eyigor, Aysegul Gozalan, Zeynep Gulay, Deniz Gur, Nezahat Gurler, Ufuk Hasdemir, Ipek Mumcuoglu, Ahmet Muezzinoglu, Cuneyt Ozakin, Duygu Percin). 


\section{REFERENCES}

1. Antimicrobial resistance: global report on surveillance. World Health Organization. 2014. http://www. who.int/drugresistance/documents/ surveillancereport/en/ Accessed December 12, 2015.

2. National Antimicrobial Resistance Surveillance System, NAMRSS: Annual Report 2011. http:// uamdss.thsk.gov.tr/index.php?option=com_phoc adownload\& view=category\&id=6: raporlar\&ltem id=13 Turkish, Accessed December 12, 2015.

3. Heuer O. EARS-Net Results-2011. Surveillance Section. European Centre for Disease Prevention and Control (ECDC). http://ecdc.europa.eu/ en/activities/diseaseprogrammemes/arhai/ presentations2011warsaw/arhai-networksmeeting_plenary-session-two-2-oler-heuer.pdf Accessed December 12, 2015

4. Gözalan A, Çöplü N, Aktaș D, Şimșek H, Erdem GB, Mumcuoğlu i. Performance evaluation of the microbiology laboratories in Turkey for culture and antibiotic susceptibility tests and the selection of laboratories to provide data for National Antimicrobial Resistance Surveillance System: Questionnary application. Turk Hij Den Biyol Derg. 2015; 72(3): 175 - 182.

5. National Antimicrobial Resistance Surveillance System Laboratory tests, Quality control and quality assurance standard opreating procedure and WHONET software porgramme. 2011, February. ISBN: 978-975-590-347-7.

6. Çöplü N, Gülay Z, Temel F, Şimșek H, Göl N, Aktaș D et al. National Antimicrobial Resistance Surveillance System External Quality Assurance Proficiency Assesment Study P129. XXXV. Turkish Microbiology Congress. 3-7 November 2012, Kușadası, Aydın, Turkey.
7. Laboratory Assessment Tool, World Health Organization. http://www.who.int/ihr/ publications/laboratory_tool/en/.

8. International Health Regulations (2005). Second ed. WHO, http://www.who.int/ihr/ publications/9789241596664/en/ Accessed December 12, 2015.

9. EARSS Annual Report 2008: On-going surveillance of S. pneumoniae, S. aureus, E. coli, E. faecium, E. faecalis, K. pneumoniae, P. aeruginosa. http:// ecdc.europa.eu/en/activities/surveillance/EARSNet/Documents/2008_EARSS_Annual_Report.pdf Accessed October 27, 2015.

10. By-law on the Surveillance and Control Principles of Communicable Diseases (amendment). Official Journal 02/04/2011 - 27893. http://www. resmigazete.gov.tr/main.aspx?home=http://www. resmigazete.gov.tr/eskiler/2011/04/20110402. htm\&main=http: / / www. resmigazete.gov.tr / eskiler/2011/04/20110402.htm Turkish, Accessed December 12, 2015.

11. Decision No $2119 / 98 / E C$ of the European Parliament and of the Council of 24 September 1998 setting up a network for the epidemiological surveillance and control of communicable diseases in the Community. http://eur-lex.europa.eu/ resource. html?uri=cellar:b97ab1a4-21f5-49de9964-bc25617d3485.0008.02/DOC_1\&format=PDF Accessed December 12, 2015.

12. Commission Decision (No 2000/96/EC) of 22 December 1999 on the communicable diseases to be progressively covered by the Community network under Decision No 2119/98/EC of the European Parliament and of the Council. http:// eur-lex.europa.eu/legal-content/EN/TXT/PD $\mathrm{F} /$ ?uri=CELEX:32000D0096\&from=EN Accessed December 12, 2015. 
13. ECDC TECHNICAL REPORT. EU Laboratory Capability Monitoring System (EULabCap) Report on 2013 survey of EU/EEA country capabilities and capacities. Stockholm, February. 2016. doi $10.2900 / 63194$

14. Central Asian and Eastern European Surveillance of Antimicrobial Resistance, Annual Report 2014. 2015. World Health Organization, Regional Office for Europe. http://www.euro.who.int/_data/assets/ pdf_file/0006/285405/CEASER-SurveillanceAntimicrobial-Resistance2014.pdf?ua=1.

15. SURVEILLANCE REPORT. Antimicrobial Resistance Surveillance in Europe, 2014. Antimicrobial resistance surveillance in Europe Annual report of the European Antimicrobial Resistance Surveillance Network (EARS-Net) 2014. Stockholm, November 2015. doi $10.2900 / 23549$.
16. Joint WHO - CDC Conference on Health Laboratory Quality Systems. WHO/HSE/IHR/LYO/2008.3 Lyon, France, 9 - 11 April 2008. http://www.who.int/ ihr/lyon/report20080409.pdf Accessed December 12, 2015.

17. Laboratory Quality Management System: Handbook. World Health Organization. ISBN: 978 924154827 4. 2011. http://whqlibdoc. who. int/publications/2011/9789241548274_eng.pdf Accessed December 12, 2015. 